\title{
Effects of TLR4 Variants on Fasting Glucose Levels in a Korean Population
}

\author{
Gi Tae Kim ${ }^{1}$, Jae Woong Sull ${ }^{1,2}$, Sun Ha Jee ${ }^{3}$ \\ ${ }^{1}$ Department of Senior Healthcare, General Graduate School, Eulji University, Seongnam, Korea \\ ${ }^{2}$ Depratment of Biomedical Laboratory Science, College of Health Science, Eulji University, Seongnam, Korea \\ ${ }^{3}$ Department of Epidemiology and Health Promotion, Institute for Health Promotion, Graduate School of Public Health, Yonsei University, Seoul, Korea
}

\section{한국인에서 TLR4 변이가 공복 시 혈당에 미치는 효과}

\author{
김기태 ${ }^{1}$, 설재웅 ${ }^{1,2}$, 지선하 $^{3}$ \\ ${ }^{1}$ 을지대학교 대학원 시니어헬스케어학과, ${ }^{2}$ 을지대학교 보건과학대학 임상병리학과, ${ }^{3}$ 연세대학교 보건대학원
}

\begin{abstract}
Diabetes mellitus is associated with a variety of adverse health outcomes, including metabolic syndrome and cardiovascular diseases. Recently, diabetes has been receiving increased scientific attention because of the rapid increase in the diabetic population. One of the features of type-2 diabetes mellitus is an elevated glucose level in blood. Fasting glucose level, which is the most basic test, is widely used as a diagnostic indicator of diabetes. Several previous studies reported that TLR4 expression is relatively high in the heart. However, few studies have investigated the association between TLR4 variants and fasting blood glucose to date. Thus, this study tested the association between single nucleotide polymorphisms (SNPS) in the TLR4 gene and fasting glucose in the Korean population. A total of 994 subjects recruited from Seoul were used for the present study. When compared to fasting blood glucose, the TLR4 gene region was shown as a linkage disequilibrium owing to the relatively large gene range. This region also presented as several LD blocks. We found that specific SNPs in the TLR4 gene were associated with the mean fasting glucose ( $p<0.01)$. The minor allele frequency of rs 1329067 was $16.4 \%$, and individuals with the AA genotype had a higher fasting blood glucose level than those with the GG genotype, suggesting that genetic variants in TLR4 influence glucose levels in Korean adults.
\end{abstract}

Key words: TLR4, Fasting blood glucose, Single nucleotide polymorphisms

This is an Open Access article distributed under the terms of the Creative Commons Attribution Non-Commercial License (http://creativecommons.org/licenses/by-nc/4.0) which permits unrestricted non-commercial use, distribution, and reproduction in any medium, provided the original work is properly cited.

Copyright @ 2017 The Korean Society for Clinical Laboratory Science. All rights reserved.
Corresponding author: Jae Woong Sull Depratment of Biomedical Laboratory Science, College of Health Science, Eulji University, 553 Sansung-daero, Seongnam 13135, Korea Tel: 82-31-740-7318 Fax: 82-31-740-7354 E-mail: jsull@eulji.ac.kr

Received: July 20, 2017 Revised $1^{\text {st. }}$ August 29, 2017 Revised $2^{\text {nd }}:$ September 5, 2017 Revised ${ }^{\text {rd }}$ : September 12, 2017 Revised $4^{\text {th }}$ : September 20, 2017 Accepted: September 20, 2017

\section{서 론}

당뇨병은 흔한 신진 대사 질환으로 많은 사람들이 당뇨병으 로 인한 조기사망의 위험에 빠질 수 있다. 특히, 제2형 당뇨병의 합병증은 인체에 다양한 질환을 일으키는 위험인자이다. 당뇨 병의 조기 발견과 그에 따른 빠른 치료로 당뇨병을 지연시키거 나 예방하는 것과 당뇨병 대상자의 진단도 중요시 되고 있다
[1,2]. TLR4 유전자는 비만과 관련이 있는 유전자로 알려져 있 지만 당뇨병과도 밀접한 관계가 있다고 알려져 있다[3].

TLR4 유전자는 막 통과 단백질로 감염시 미생물 검출에 관여 하며 숙주의 면역 방어에서 중요한 역할을 한다[4]. 포유류의 TLR4는 그람음성균의 lipopolysaccharide를 인식하는 막관 통 수용체다[5]. TLR4의 신호전달 경로의 활성화는 NF- $\mathrm{kB}$, $\mathrm{AP}-1$, interferon regulatory factors등의 여러 전사인자들 상 
향 조절을 통해 사이토카인 생성을 유도한다[6].

TLR4 유전자는 비만인 사람과 제2형 당뇨병인 사람에게서 발현이 증가되었으며, 유리 지방산과 염증, 선천 면역계간 분자 적 연결이라고 보고되고 있다[7,8]. TLR4 유전자의 단일염기다 형성(SNP)이 제2형 당뇨병과 높은 체질량지수(BMI)와 관련이 있었으나 실제 연구 결과값이 명확하지 않았고, 초기 연구에서 는 TLR4D299G/T3991와당뇨병 유병률과의 관련을 확인하지 못했다고 하였다[9,10]. 그러나, 이후 연구에서 고밀도콜레스 테롤 수치에 의존하는 TLR4D299G/T399I를 가진 남성백인이 제2형 당뇨병으로 진행할 위험이 더 높다고 보고하였다[11]. 그 리고 제2형 당뇨병의 큰 특징 중 하나는 인슐린 분비 결함과 말 초저항에 의해 고혈당이 된다고 보고되고 있다[12]. 고혈당의 지속적인 상태는 인체에 치명적이며, 혈당 조절은 당뇨병의 이 환율과 사망률에 관련이 있다[13,14]. 본 연구에서는 TLR4 유 전자의 단일염기다형성(SNP) 자료와 공복 시 혈당과의 관련성 을 조사하였다.

\section{대상 및 방법}

\section{1. 연구 대상}

연구 대상자는 2006년 1월부터 2007년 6월까지 서울지역 종합병원 건강검진센터에 방문하여 대사증후군 연구 사업에 참 여한 6,622명 중 신체계측(키, 체중, 허리둘레, 혈압)과 혈액검 사(아디포넥틴, 고밀도콜레스테롤, 중성지방, 공복 시 혈당), 맥 파전파속도, 문진(흡연)자료누락이 있는 대상자를 제외하고, 나머지 3,390명(남자 1,940명, 여자 1,450명)을 대상으로 하였 습니다. 이 중 1,004 명에 대하여 전장유전체 다형성 분석을 진 행한 참여대상자들의 사전 동의를 구하였으며, 분석률이 낮거 나 유전자 분석과 성별이 불일치한 10명을 제외하고 994 명을 대상으로 하였다. 연구계획에 대하여 을지대학교 IRB (Institutional Review Board of Human Research at Eulji University)의 승인을 얻었다(IRB No: EUIRB2016-15).

\section{2. 자료수집}

구조화된 설문지를 이용하여 인구 사회학적 특성(나이, 성별, 가족력 등)과 흡연력, 음주력 등을 설문조사 하였다. 흡연력은 비흡연, 과거흡연, 현재흡연으로 구분하여 질문하였으며, 음주 력은 현재 술을 안 마신다와 마신다로 구분하였다. 어리둘레는 줄자를 이용하여 장골과 마지막 늑골사이의 중간부위를 수평으 로 측정하는 것을 원칙으로 하였으며, 정확한 위치를 가늠하기 어려운 경우는 배꼽 위 $3 \mathrm{~cm}$ 를 측정하였다. 키와 몸무게는 간단
한 옷만 입은 채 측정하였다. BMI는 체중 $(\mathrm{kg}) /$ 키 $\left(\mathrm{m}^{2}\right)$ 으로 계산 하였다. 수축기 혈압과 이완기 혈압 모두 15 분 안정을 취한 후측 정하였다. 혈압에 대한 구분은 미국 JNC 7 (Seventh Report of the Joint National Committee on the Prevention) 기준에 따 라서 수축기혈압, 이완기혈압이 각각 $120 / 80 \mathrm{mmHg}$ 는 normal, 120-139/80-89는 prehypertension, 140-159/90-99 는 Stage 1 hypertension, $\geq 160 / \geq 100$ 은 Stage 2 hypertension 으로 구분하였다.

\section{3. 생화학적 검사}

모든 대상자는 12 시간 이상 금식 후에 혈액을 채취하여 원심 분리 후 영하 70 도로 냉동시켰다. 대사증후군 지표인 공복 시 혈 당과총콜레스테롤, 중성지방, 고밀도콜레스테롤을 Hitachi-7600 자동생화학분석기(Hitachi, Tokyo, Japan)를 이용하여 측정하 였으며, 연구 대상자들의 검사 결과를 연구 자료로 활용하였다.

\section{4. 유전자 분석}

Affymetrix Genome-Wide Human SNP array 5.0 (Affymetrix, Santa Clara, CA, USA)을 이용하여 유전자 분석 을 시행하였으며 quality control call rate (dynamic model algorithm)는 $86 \%$ 이상을 나타내었고, $\mathrm{X}$ 염색체 상의 heterozygosity로 대상자 개개인의 성별을 정확하게 구별하였 다. Genotype calling은 birdseed v2 algorithm을 통해 시행하 였다. 표본의 분석률이 낮거나 $(<90 \%, \mathrm{MIND}$ (missing rate per individual) $>0.1$ 기준 적용), PLINK를 이용하여 identity-by-sate (IBS) 산출식으로 전체 SNP를 분석하여 유전 적으로 연관성을 가진 표본을 제외하였다.

\section{5. 통계 분석}

통계 프로그램은 plink 프로그램과 haploview 프로그램을 사용하였고 통계 분석과정에서 minor allele frequency (MAF) $5 \%$ 이하인 SNP들을 제외시켰다. 다중선형 회귀분석을 시행하 였고 통제변수는 연령과 성별이었다. 다중선형회귀분석에서 공복 시 혈당과의 가장 높은 통계적 유의성을 보인 5 개의 $\mathrm{SNP}$ 를 선정하였다. 연구 대상자의 일반적 특성에 대한 분포 등 연속형 자료는 평균 (mean $\pm \mathrm{SD}$ )으로 표시하였다. 또한, 모든 경우에 서 2 tailed significance를 구하였고, $p<0.05$ 를 통계적으로 유 의한 것으로 간주하였다. 


\section{결 과}

\section{1. 연구대상자의 일반적인 특성}

Table 1과 같이 전체 연구대상자는 994명이었다. 남자 561 명(56.4\%), 여자 433명(43.6\%)이었고, 평균 연령은 41.5 세이

Table 1. General characteristics of study population
Subjects $(N)$

Male gender (\%)

Age, year

Waist circumference, $\mathrm{cm}$

Body mass index, $\mathrm{kg} / \mathrm{m}^{2}$

Fasting blood sugar, $\mathrm{mg} / \mathrm{dL}$

Systolic blood pressure, $\mathrm{mmHg}$

Diastolic blood pressure, $\mathrm{mmHg}$

HDL cholesterol, $\mathrm{mg} / \mathrm{dL}$

LDL cholesterol, $\mathrm{mg} / \mathrm{dL}$

Triglyceride, $\mathrm{mg} / \mathrm{dL}$

Smoking status

Alcohol drinking

Diabetes
994

56.4

Mean \pm SD

$81.1 \pm 9.7$

$23.7 \pm 3.1$

$93.8 \pm 16.4$

$120.9 \pm 13.8$

$73.9 \pm 10.4$

$54.2 \pm 12.9$

$108.7 \pm 29.2$

$118.1 \pm 93.4$

N (\%)

$550(55.3)$

$116(16.7)$

$278(28.0)$

754 (77.3)

$52(5.2)$
$41.5 \pm 8.5$

Abbreviations: HDL, high density lipoprotein; LDL, low density lipoprotein; SD, standard deviation.
었다. 또한, 체질량지수(body mass index, BMI)는 $23.7 \mathrm{~kg} / \mathrm{m}^{2}$ 이었으며, 공복 시 혈당은 $93.8 \mathrm{mg} / \mathrm{dL}$ 이었다. HDL 콜레스테롤 의 경우 $54.2 \mathrm{mg} / \mathrm{dL}$ 이었다. 그 외에 다른 검사 결과들과 함께 대상자들의 일반적인 특성을 나타냈다. 당뇨병 여부에 대한 분 석에서는 전체 대상자의 $5.2 \%$ 가 당뇨병이 있었다. 당뇨병에 대 한 정의는 공복 시 혈당이 $125 \mathrm{mg} / \mathrm{dL}$ 를 초과하거나 당뇨병 치 료를 받은 적이 있는 경우로 하였다.

\section{2. 유전체 관련성 분석과 연관불균등(linkage disequilibrium,}

\section{LD) 검사}

Figure 1과 같이 TLR4 유전자의 단일염기다형성(SNP)중, rs1329067이 공복 시 혈당과 가장 높은 관련성을 보였다 $(p$ <0.01). 서울시 코호트 그룹(N=994)의 TLR4 유전자 부위에 따른 공복 시 혈당과 관련해서 연관불균등을 나타내었는데, 공 복 시 혈당과 관련 크기는 $p$-value를 $-\log ^{10}$ 의 값으로 하였다. 그리고, 선형 회귀 모델을 각 SNP에 사용 했으며, 연관불균등은 유전자의 범위가 매우 컸기 때문에 여러개의 $\mathrm{LD}$ 블록으로 나타 났다.

\section{3. 선형회귀분석에서의 공복 시 혈당과의 유전체 관련성 분석}

Table 2와 같이 TLR4 유전자에서 공복 시 혈당과의 관련성 에서 top 5인 단일염기다형성(SNP)을 나타낸다. rs1329067이

A

Chromosome 9

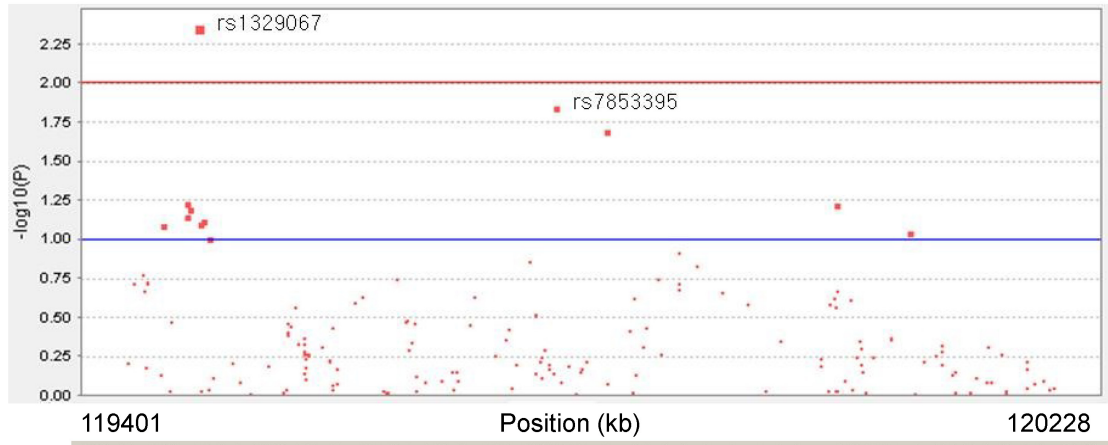

B

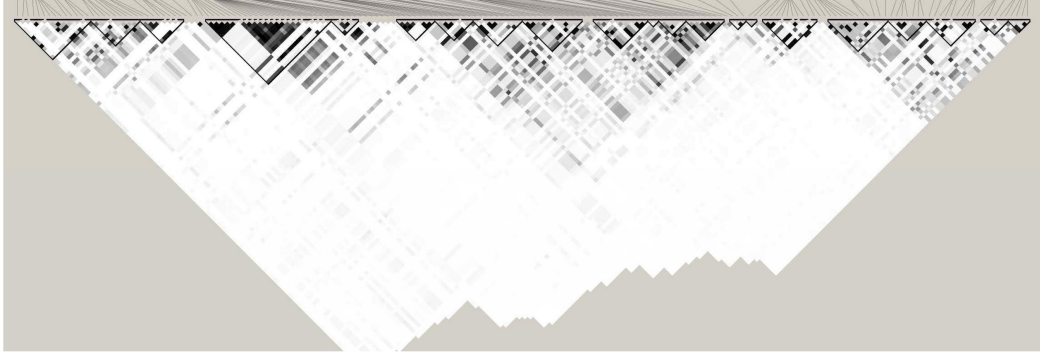

Figure 1. Plots of fasting blood glucose association and Linkage disequilibrium for the TLR4 gene region in Seoul City cohorts ( $N=994$ ). (A) The upper panel shows the association magnitude $(-\log 10(p$-value)) with fasting blood glucose. A linear regression model, including age and gender, was used for each individual SNP. The lower panel shows the TLR4 gene structure. (B) Linkage disequilibrium as measured by $R^{2}$ in TLR4 based on genotyping data from 994 subjects (White: $R^{2}=0$. Shades of gray: $0<R^{2}<1$. Black: $R^{2}=1$ ). 
Table 2. The 5 TLR4 SNPs most strongly associated with fasting blood glucose based on a linear regression model

\begin{tabular}{ccccc}
\hline SNP & Position & MAF & $\begin{array}{c}\text { Effect }^{\star} \\
(\mathrm{mg} / \mathrm{dL})\end{array}$ & $p$-value \\
\hline rs1329067 & 119462020 & 0.163968 & 2.756 & 0.00435 \\
rs7853395 & 119781464 & 0.0356037 & 4.658 & 0.0144 \\
rs2809420 & 119826846 & 0.0863273 & 2.903 & 0.02043 \\
rs7020245 & 119452898 & 0.422032 & -1.336 & 0.05801 \\
rs1410201 & 120032590 & 0.451098 & 1.329 & 0.05968 \\
\hline
\end{tabular}

*Estimated effect size ( $\beta$ ) for the 5 most significant SNPs identified from Seoul City cohort ( $\mathrm{N}=994)$ and associated $p$-value in multiple linear regression model considering age and sex under an additive model.

Abbreviations: SNP, single nucleotide polymorphism; MAF, minor allele frequency.

$p$-value 0.004 로 통계적으로 가장 유의한 결과를 얻었다. rs1329067의 minor allele의 빈도는 $16.4 \%$ 이었다. 그 다음으 로 높은 관련성을 보인 단일염기다형성(SNP)은 rs7853395이 다 $(p=0.0144)$. 또한, Table 3와 같이 유전자형에 따른 공복 시 혈당의 평균값을 나타내었으며, rs1329067의 경우에는 AA유 전자형을 가진 사람이 GG유전자형을 가진 사람보다 공복 시 혈 당이 더 높았다.

\section{고 찰}

본 연구에서는 제2형 당뇨병과 관련이 있는 TLR4 유전자에 대하여 염기서열다형성 지표와 공복 시 혈당과의 관련성을 확 인하여 한국 일반 성인에서 TLR4가 당뇨병과 관련이 있음을 제 안하였으며, 여러 선행 연구에서 TLR4 유전자와 TLR4 신호 경 로가 비만과 인슐린 저항성에 미치는 영향을 밝혀내고 TLR4 유 전자가 제2형 당뇨병 발병에 관련성이 있다고 알려져 있다 [15-18]. 한 연구에서는 TLR4 유전자가 쥐를 대상으로 비만과 인슐린 저항성에 관련성이 있다고 보고하였다[15]. 그리고 TLR4 유전자는 고밀도콜레스테롤과 2-h plasma glucose 수 치에서 유의성을 보이며 제2형 당뇨병과 관련성이 있으며, 비만 과 과체중인 사람에서 TLR4 유전자의 관련성이 있다고 보고되 었다[16,17]. 한편으로, TLR4의 SNP는 중국 인구에서 제2형 당뇨병과 관련성이 있다[18].

본 연구에서는 공복 시 혈당과 rs1329067이 가장 높은 관련 성을 보였다. 나이와 성별만을 통제한 분석에서 SNP rs1329067 은 선형회귀분석에서 $p$-value 0.004 의 관련성을 가졌다. 나이, 성별 이외에 당뇨병 여부 변수를 함께 통제하여 분석을 하였을 때에는 선형회귀분석에서 $p$-value 0.008 의 관련성을 가졌다. 단일염기다형성(SNP)인 rs1329067의 빈도는 다른 인구에서 다
Table 3. Mean of fasting glucose levels by genotypes of TLR4 SNP rs1329067

\begin{tabular}{ccccc}
\hline \multicolumn{2}{c}{ Mean of fasting glucose levels (SD) } & $F$ & $p$-value \\
\hline $\mathrm{A} / \mathrm{A}$ & $\mathrm{A} / \mathrm{G}$ & $\mathrm{G} / \mathrm{G}$ & & \\
$(\mathrm{N}=18)$ & $(\mathrm{N}=281)$ & $(\mathrm{N}=676)$ & & \\
$97.8(10.1)$ & $96.0(22.2)$ & $92.9(13.0)$ & 3.96 & 0.019 \\
\hline
\end{tabular}

Calculated by the analysis of variance (ANOVA).

르게 나타났다. A 대립유전자의 빈도는 유럽인에게서는 $12.9 \%$, 사하라사막계 아프리카인에서는 $16.4 \%$, 멕시코계 미국인에게 서는 $15 \%$ 이었으며, 동아시아인에서는 베이징계 한족에서 $19.8 \%$, 일본인에게서 $16.9 \%$ 로 보고되었다[19]. 하지만 국내에 서는 TLR4 유전자와 당뇨병에 대한 임상적인 연구가 많이 이루 어지지 않았기 때문에 추가적인 연구가 많이 이루어져야 할 것 으로 판단된다. 그리고 TLR4 유전자가 염증(inflammation)의 좋은 지표임을 감안할 때 향후 염증과 관련이 있는 다른 지표에 대한 추가 분석이 필요하다. 또한, 본 연구는 단면 연구(Cross section study)이고, 표본수가 크지 않으므로 인과 관계를 밝히 는데 제한점이 있다. 또한, 통계 분석에서 다중검정(Multiple testing)을 통제하지 못한 한계가 있다. 따라서, 추후 다른 대규 모 연구에서 확인이 필요하겠다.

\section{요 약}

당뇨병은 대사 증후군 및 심혈관 질환을 비롯한 다양한 건강 상의 부작용과 관련이 있다. 또한 당뇨병의 증가로 사회 및 의학 적 관심이 증가하고 있다. 제 2 형 당뇨병의 특징 중 하나는 혈당 이 증가한다는 것이다. 공복 혈당치는 가장 기본적이고 널리 사 용되는 당뇨병의 지표이다. TLR4 발현은 심장에서 비교적 높 다. 그러나 공복 시 혈당과 TLR 4 의 관련성에 대한 연구가 있었 다. 한국인에서 TLR4 유전자와 공복 시 혈당의 단일 염기 다형 성(SNP)의 관련성을 알아 보았다. 서울시에서 총 994 명을 대상 으로 TLR4 SNP를 이용한 연구를 실시했다. 공복 시 혈당과 관 련하여 TLR4 유전자 영역은 연쇄 불균형으로 나타 났으며 유전 자의 범위가 매우 크기 때문에 여러 개의 $\mathrm{LD}$ 블록으로 보였다. TLR4 유전자의 SNP는 평균 공복 시 혈당과 관련이 있었다 $(p$ $<0.01)$. 공복 시 혈당과 관련 크기는 $p$-value를 $-\log ^{10}$ 의 값으 로 하였다. rs1329067의 minor allele frequency는 $16.4 \%$ 였 고 $\mathrm{AA}$ 유전자형을 가진 사람들은 $\mathrm{GG}$ 유전자형을 가진 사람들 보다 공복시 혈당이 높았다. 이 연구는 TLR4의 유전 적 변이가 한국 성인의 혈당 수치에 영향을 미친다는 것을 암시한다. 
Acknowledgements: This paper was supported by Eulji University in 2017 (EJRG-16-10-12) and the Ministry of Education (NRF-2015R1D1A1A01059651).

Funding: None

Conflict of interest: None

\section{REFERENCES}

1. Prasad-Reddy L, Isaacs D. A clinical review of GLP-1 receptor agonists: efficacy and safety in diabetes and beyond. Drugs Context. 2015:4:212283.doi:10.7573/dic.212283.

2. Kwon SY, Na YA. The cutoff value of HbA1c in predicting diabetes and impaired fasting glucose. Korean J Clin Lab Sci. 2017; $49(2): 114-120$.

3. Li M, Song L, Gao X, Chang W, Qin X. Toll-like receptor 4 on islet $\beta$ cells senses expression changes in high-mobility group box 1 and contributes to the initiation of type 1 diabetes. Exp Mol Med. 2012;44(4):260-7.

4. Trudler D, Farfara D, Frenkel D. Toll-like receptors expression and signaling in glia cells in neuro-amyloidogenic diseases: towards future therapeutic application. Mediators Inflamm. 2010;2010. http://dx.doi.org/10.1155/2010/497987.

5. Poltorak A, Smirnova I, He X, Liu MY, Van Huffel C, McNally O, et al. Genetic and physical mapping of the Lps locus: identification of the toll- 4 receptor as a candidate gene in the critical region. Blood Cells Mol Dis. 1998;24(3):340-355.

6. O'Neill LA, Golenbock D, Bowie AG. The history of Toll-like receptors - redefining innate immunity. Nat rev Immunol. 2013; 13(6):453-460.

7. Shi H, Kokoeva MV, Inouye K, Tzameli I, Yin H, Flier JS. TLR4 links innate immunity and fatty acid-induced insulin resistance. J Clin Invest. 2006;116(11):3015-3025.

8. Reyna SM, Ghosh S, Tantiwong P, Meka CS, Eagan P, Jenkinson $\mathrm{CP}$, et al. Elevated toll-like receptor 4 expression and signaling in muscle from insulin-resistant subjects. Diabetes. 2008; 57(10):2595-2602.

9. Weyrich P, Staiger H, Stančáková A, Machicao F, Machann J, Schick F, et al. The D299G/T399I Toll-like receptor 4 variant associates with body and liver fat: results from the TULIP and METSIM Studies. PLoS One. 2010;5(11):e13980. doi:10.1371/ journal.pone.0013980.

10. Illig T, Bongardt F, Schöpfer A, Holle R, Müller S, Rathmann W, et al. The endotoxin receptor TLR4 polymorphism is not associated with diabetes or components of the metabolic syndrome. Diabetes. 2003;52(11):2861-2867.

11. Kolz M, Baumert J, Müller M, Khuseyinova N, Klopp N, Thorand $\mathrm{B}$, et al. Association between variations in the TLR4 gene and incident type 2 diabetes is modified by the ratio of total cholesterol to HDL-cholesterol. BMC Med Genet. 2008;9:9. doi:10.1186/1471-2350-9-9.

12. de Araújo MFM, Veras VS, de Freitas RWJF, de Paula MDL, de Araújo TM, Uchôa LRA, et al. The effect of flour from the rind of the yellow passion fruit on glycemic control of people with diabetes mellitus type 2: a randomized clinical trial. J Diabetes Metab Disord. 2017;16(4):18. doi:10.1186/s40200-017-0300-z.

13. American Diabetes Association. Standards of medical care in diabetes-2013. Diabetes Care. 2013;36(suppl1):11-66. https:// doi.org/10.2337/dc13-S011.

14. Dom M, Calder A, Mat R. Clinical epidemiological characteristics of acute complications of diabetes in the emergency ward at Atizapan General Hospital. Rev Fac Med. 2013;56(2):25-36.

15. Al-Daghri NM, Clerici M, Al-Attas O, Forni D, Alokail MS, Alkharfy KM, et al. A nonsense polymorphism (R392X) in TLR5 protects from obesity but predisposes to diabetes. J Immunol. 2013;190(7):3716-3720.

16. Peng D, Jiang F, Zhang R, Tang S, Chen M, Yan J, et al. Association of Toll-like Receptor 4 Gene polymorphisms with susceptibility to type 2 diabetes mellitus in the Chinese population. J Diabetes. 2015;7(4):485-492.

17. Ahmad R, Al-Mass A, Atizado V, Al-Hubail A, Al-Ghimlas F, $\mathrm{Al}$-Arouj $\mathrm{M}$, et al. Elevated expression of the toll like receptors 2 and 4 in obese individuals: its significance for obesity-induced inflammation. J Inflamm (Lond). 2012;9(1):48. doi:10.1186/ 1476-9255-9-48.

18. Jiang ZS, Wang SX, Jia HX, Wang J, Liu YT. Association of toll-like receptor 4 polymorphisms with type 2 diabetes mellitus. Inflammation. 2013;36(1):251-257.

19. U.S. National Library of Medicine. Reference SNP (refSNP) Cluster Report: rs1329067 [Internet]. Rockville: National Center for Biotechnology information; 2013 [cited 2017 June 16]. Available from: https://www.ncbi.nlm.nih.gov/projects/SNP/snp_ref.cgi?rs=1329067. 